\title{
Egg Development of the Ussurian Bullhead Fish, Leiocassis ussuriensis (Pisces: Bagridae) and Morphological Development of Its Larvae and Juveniles
}

\author{
Jae-Min Park ${ }^{1}$, Hu-Sun Yim ${ }^{1}$, Yong-Sik Lee ${ }^{2}$, Heung-Yun Kim ${ }^{3}$ and ${ }^{\dagger}$ Kyeong-Ho Han ${ }^{2}$ \\ ${ }^{1}$ Gyeongsangbuk-do Native Fish Business Center, Uiseong 37366, Korea \\ ${ }^{2}$ Dept. of Aqualife Science, Chonnam National University, Yeosu 59626, Korea \\ ${ }^{3}$ Dept. of Aqualife Medicine, Chonnam National University, Yeosu 59626, Korea
}

\begin{abstract}
This study was examined the ovogenesis of Ussurian bullhead, Leiocassis ussuriensis and the morphological development of its larvae and juveniles and to use the results as basic information for the preservation of species and resource enhancement. For artificial egg collection, human chorionic gonadotropin (HCG) was injected at a rate of 10 IU per gram of fish weight. During breeding period, water temperature maintained at $24.5 \sim 26.5^{\circ} \mathrm{C}$ (mean $25.0 \pm 0.05^{\circ} \mathrm{C}$ ). The process of ovogenesis reached the two-cell stage in 50 minutes after fertilization. In 73 hours of fertilization the movement of the embryoid body became active state and the larvae began to hatch from the tail through the oolemma. Length of prelarvae were $6.33 \sim 6.50 \mathrm{~mm}$ long (mean $6.40 \pm 0.06 \mathrm{~mm}$ ) just after hatching having yolk with their mouth not opened. After thirty eight days of hatching, juveniles were $30.6 \sim 32.5 \mathrm{~mm}$ long (mean $31.5 \pm 0.65 \mathrm{~mm}$ ). The color was dark yellowish brown throughout the entire body, and the number of caudal fin rays developed to thirty six perfectly.
\end{abstract}

Key words : Egg development, Juvenile, Larvae, Leiocassis ussuriensis

\section{INTRODUCTION}

Leiocassis ussuriensis is a fish of order Siluriformes, family Bagridae, genus Leiocassis, and there are six species of two genuses in the same family reported to inhabit Korea, which are Leiocassis ussuriensis, L. longirostris, $L$. nitidus, Pseudobagrus brevicorpus, P. fulvidraco, and $P$. koreanus (Kim et al., 2005; NIBR, 2011).

Previous works on the fishes of family Bagridae studied taxonomic review (Lee \& Kim, 1990), the egg development P. aurantiacus and the morphological development of its larva and juvenile (Takeshita \& Kimura, 1994), the spawning behavior and larva development of P. ichikawai (Watanabe, 1994), early life history of $P$. fulvidraco (Kang \& Lee, 1996), early life history of $P$. koreanus (Kang, 1998), ovulation induction (Park et al., 1998), the spawning behavior of P. nudiceps (Matsuo \& Takahama, 2004), the ecology of Pseudobagrus brevicorpus (Kang et al., 2007), development of breeding technology (Lim, 2009), development of early seed production technology (Bang \& Baek, 2011), etc., but few studies have been made on the life history of Leiocassis ussuriensis and the growth cha-

\footnotetext{
Manuscript received October 10, 2015, Received in revised form October 25, 2015, Accepted November 1, 2015

${ }_{\dagger}$ Corresponding Author : Kyeong-Ho Han, Dept. of Aqualife Science, Chonnam National University, Yeosu 59626, Korea. Tel : +82-61-659-7160, Fax : +82-61-659-7169, E-mail : gost016803@naver.com

This is an Open Access article distributed under the terms of the Creative Commons Attribution Non-Commercial License (http:// creativecommons.org/licenses/by-nc/3.0) which permits unrestricted non-commercial use, distribution, and reproduction in any medium, provided the original work is properly cited.
} 
racteristics of its larva and juvenile.

As Leiocassis ussuriensis shows a high growth rate among the varieties of $P$. fulvidraco and is highly preferred as edible fish, it is spotlighted as a new species for farming and recently it was included as one of fish species for seed production and ovulation induction. With these, there are an increasing number of fishery households wanting to produce its juveniles and to grow edible fish (Lee, 2012). On the other hand, the seeds of Leiocassis ussuriensis are produced from wild broodstock, but reckless overfishing is likely to shrink the population.

Thus, as part of research on the early life history, this study purposed to investigate the egg development of Leiocassis ussuriensis and the morphological development of its larva and juvenile and to provide basic information for species preservation and resource enhancement.

\section{MATERIALS AND METHODS}

\section{Juvenile breeding and artificial egg collection}

For juveniles to be used in the experiment, we collected 30 female individuals (overall length $19.3 \sim 23.4 \mathrm{~cm}$, average $21.3 \pm 1.28 \mathrm{~cm}$ ) and 20 male ones (overall length 27.9 35.0 $\mathrm{cm}$, average $31.6 \pm 2.08 \mathrm{~cm}$ ) using triangular nets and fish traps at a tributary of the Nakdong River in Yecheon-gun, Gyeongsangbuk-do during the period from May to July in 2015. The collected broodstock was kept in a circular tank (Ø, 15 ton) made of polypropylene (PP), and fed with frozen fresh-water shrimp and formula feed twice a day. In artificial egg collection, human chorionic gonadotropin (HCG) was injected at a dose of $10 \mathrm{IU} / \mathrm{g}$, and then eggs were collected artificially after 22 hours and fertilized through dry fertilization.

2. Egg development process and the morphological development of larva and juvenile

From fertilized eggs, 50 eggs were sampled at random and put in a $500 \mathrm{~mL}$ glass beaker, and weak aeration was maintained. Breeding water temperature was maintained at 24.5 $26.5^{\circ} \mathrm{C}$ (average $25.0 \pm 0.05^{\circ} \mathrm{C}$ ), and half of the breeding water was changed twice a day. For egg size, egg diameter was measured up to $0.01 \mathrm{~mm}$ using a phase-contrast microscope (LEICA, Germany), and eggs developing after fertilization were observed longitudinally using a stereoscopic microscope (NIKON, Japan). Larvae just after hatching were held in a rectangular glass tank $(30 \times 25 \times 30 \mathrm{~cm})$, and bred through recirculation using a sponge filter. During the period of breeding, the larvae and juveniles were fed with Artemia from just after hatching to 20 days, and then with the mixture of Daphnia pulex and formula feed $(700 \mu \mathrm{m})$. For the morphological development of larva and juvenile, everyday from hatching, five individuals were sampled and anesthetized using anesthetic (MS-222, Ethyl 3-aminobenzoate methanesulfonate, Sigma Aldrich Co., St. Louis, USA), and the developmental characteristics of each part of the body were examined using a stereoscopic microscope and profile projector (NIKON, Japan). The stages of morphological development were divided according to Kendall (1984).

\section{RESULTS}

\section{The number of eggs and egg size}

The number of eggs of Leiocassis ussuriensis juveniles, when counted at a weight 50.1 63.3 g (average $56.5 \mathrm{~g}$ ), was 1,345 1,782 (average 1,562). The form of fertilized eggs was globular without an oil globule, and they were demersal and adhesive eggs covered with phlegm (Fig. 1A). Egg size was $2.20 \sim 2.50 \mathrm{~mm}$ (average $2.36 \pm 0.11 \mathrm{~mm}$, $\mathrm{n}=50$ ).

\section{Egg development process}

The fertilized eggs reached the 2-cell stage in 50 minutes after fertilization (Fig. 1B), 4-cell stage in 1 hour 10 minutes 
(Fig. 1C), 8-cell stage in 1 hour 50 minutes (Fig. 1D), 16cell stage in 2 hours 10 minutes (Fig. 1E), 32-cell stage in 2 hours 50 minutes (Fig. 1F), morula stage in 3 hours 20 minutes (Fig. 1G), blastula stage in 5 hours 50 minutes (Fig. 1H), and the late gastrula stage with the germinal disk covering $2 / 3$ of the yolk in 16 hours (Fig. 1I). The embryoid body was formed in 18 hours 20 minutes after fertilization (Fig. 1J), and eye vesicles were formed in the head and Kuffer's vesicles in the lower part of the tail. In 47 hours 50 minutes after fertilization, pigment deposited in the eye vesicles, the tail part began to move, and Kuffer's vesicles disappeared. The number of myotomes formed during this stage was 10 (Fig. 1K). In 73 hours 10 minutes after fertilization, a membranous fin was formed on the tail and extended long, and blood began to flow along the heart in the upper part of the yolk. Small spot-like black vesicles
A

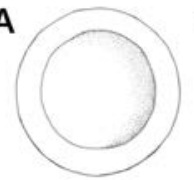

E

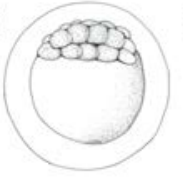

I

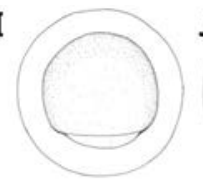

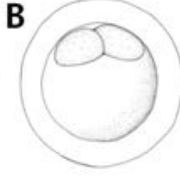

$\mathbf{F}$

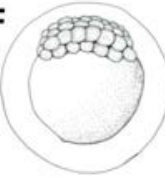

J

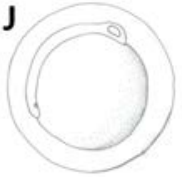

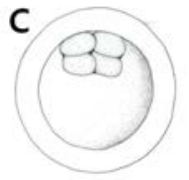

G
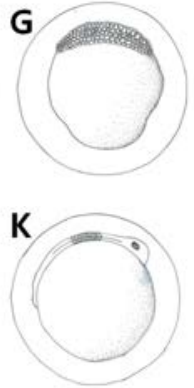

D

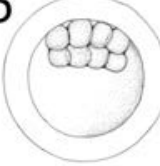

H

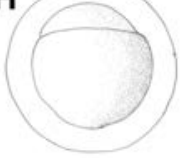

$\mathbf{L}$

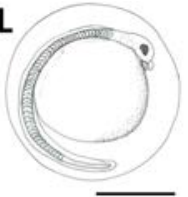

Fig. 1. The egg development of Ussurian bullhead fish,

Leiocassis ussuriensis. A: Fertilized eggs; B: 2 cells stage, 50 mins; C: 4 cells stage, 1 hrs 10 mins; D: 8 cells stage, 1 hrs 50 mins; E: 16 cells stage, 2 hrs 10 mins; F: 32 cells stage, 2 hrs 50 mins; G: Morula stage, 3 hrs 20 mins; H: Blastula stage, 5 hrs 50 mins; I: Gastrula stage, 16 hrs; J: Development of embryo, 18 hrs 20 mins; K: 10 myotomes stage, 47 hrs 50 mins; L: Embryo just before hatching, $73 \mathrm{hrs} 10 \mathrm{mins}$. Scale bar $=1.0 \mathrm{~mm}$. deposited in the head, lens was differentiated in the eyes, and a pair of barbels developed around the mouth. As the movement of the embryoid body became active and the heart rate went up, hatching was started from the tail, breaking the egg membrane (Fig. 1L).

\section{Morphological development of larva and juvenile}

For pre-larvae just after hatching, overall length was $6.33 \sim 6.50 \mathrm{~mm}$ (average $6.40 \pm 0.06 \mathrm{~mm}$ ), the mouth was not open, a pair of barbels were formed around the mouth, and the yolk was $1 / 3$ of the overall length. A membranous fin was formed from the end of the head to the end of the yolk, the anus was open, and spot-like black vesicles deposited in the head (Fig. 2A).

For pre-larvae in 3 days after hatching, overall length was $8.21 \sim 8.47 \mathrm{~mm}$ (average $8.34 \pm 0.09 \mathrm{~mm}$ ), the mouth opened and began to eat feed, and another pair of barbels developed and therefore a total of two pairs developed.

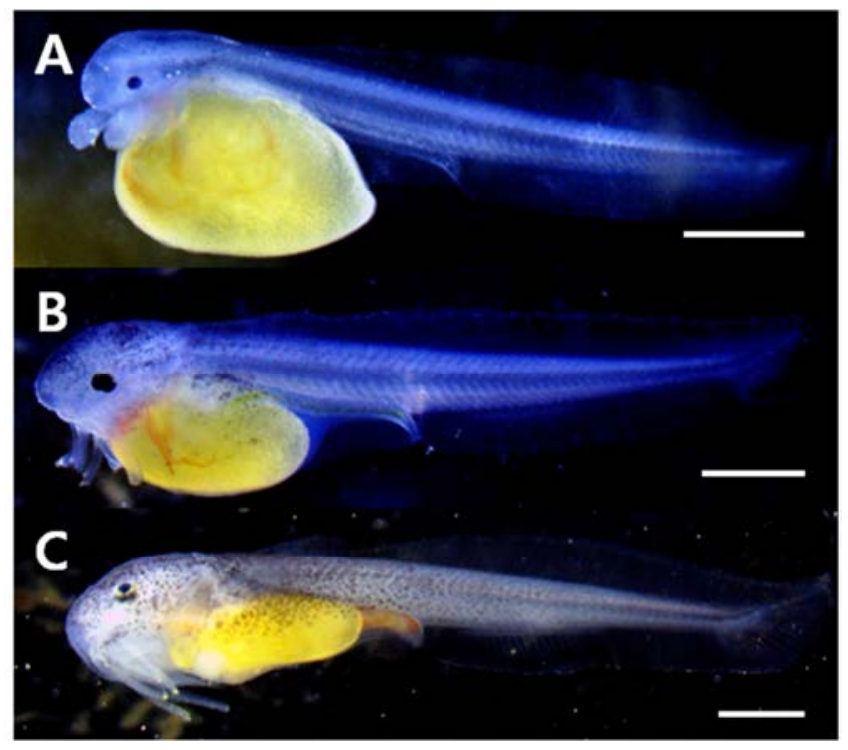

Fig. 2. Development of prelarvae and postlarvae Ussurian bullhead fish, Leiocassis ussuriensis. A: Newly hatched prelarvae; $6.43 \mathrm{~mm}$ in total length (TL); B: $8.30 \mathrm{~mm}$ in TL prelarvae, 3 days after hatching; $\mathrm{C}$ : $10.3 \mathrm{~mm}$ in TL postlarvae, 6 days after hatching. Scale bars $=1.0 \mathrm{~mm}$. 
The pectoral fin developed in a round form, and the end of the caudal fin somite began to bend $45^{\circ}$. The spot-like black vesicles deposited in the head and the upper part of the yolk were transformed into the form of branch, and the digestive tract developed as a long straight line (Fig. 2B).

For post-larvae in 6 days after hatching, overall length was $9.95 \sim 11.5 \mathrm{~mm}$ (average $10.6 \pm 0.60 \mathrm{~mm}$ ), the yolk was absorbed all, 16 soft ray anlages developed at the lower part of the trunk, and 18 soft rays were formed in the caudal fin. Black vesicles deposited in the form of branch around the mouth, and from behind the head to the center of the trunk (Fig. 2C).

For post-larvae in 10 days after hatching, overall length was $11.7 \sim 13.5 \mathrm{~mm}$ (average $12.6 \pm 0.67 \mathrm{~mm}$ ), the two pairs of barbels formed around the mouth extended long, the dorsal fin was separated from the membranous fin, and two spinous rays and six soft rays were formed. The number of soft rays formed at the lower part of the trunk increased to 19 , and the number of soft rays in the caudal fin increased to 20 and their form became like a fan. Black vesicles deposited in the soft rays of the dorsal fin, and in the membranous fins above and below the center of the trunk (Fig. 3A).

For post-larvae in 15 days after hatching, overall length was 17.2 19.5 mm (average $18.4 \pm 0.83 \mathrm{~mm}$ ), and two additional pairs of barbels were formed around the mouth, so a total of four pairs developed, reaching the whole number. The membranous fin was divided into the ventral fin, anal fin, first and second dorsal fins, and caudal fin. The number of soft rays was 6 in the ventral fin, 7 in addition to 2 spinous rays in the dorsal fin, and 24 in the caudal fin. As the membranous fin at the bottom of the trunk was separated as the anal fin, the number of soft rays increased to 21 . Black vesicles deposited in the entire body in the form of branch, and deposited in the second dorsal fin and anal fin (Fig. 3B).
For juveniles in 29 days after hatching, overall length was 24.3 26.2 $\mathrm{mm}$ (average $25.2 \pm 0.71 \mathrm{~mm}$ ), a spinous ray was formed in the pectoral fin, and serrated teeth were formed inside the mouth. The number of soft rays in the anal fin increased to 24 , and the fan-shaped end of the caudal fin developed into a round form with the center indented. Black vesicles deposited in the second dorsal fin were colored dark, and they were deposited in the caudal fin in the same pattern (Fig. 3C).

For juveniles in 38 days after hatching, overall length

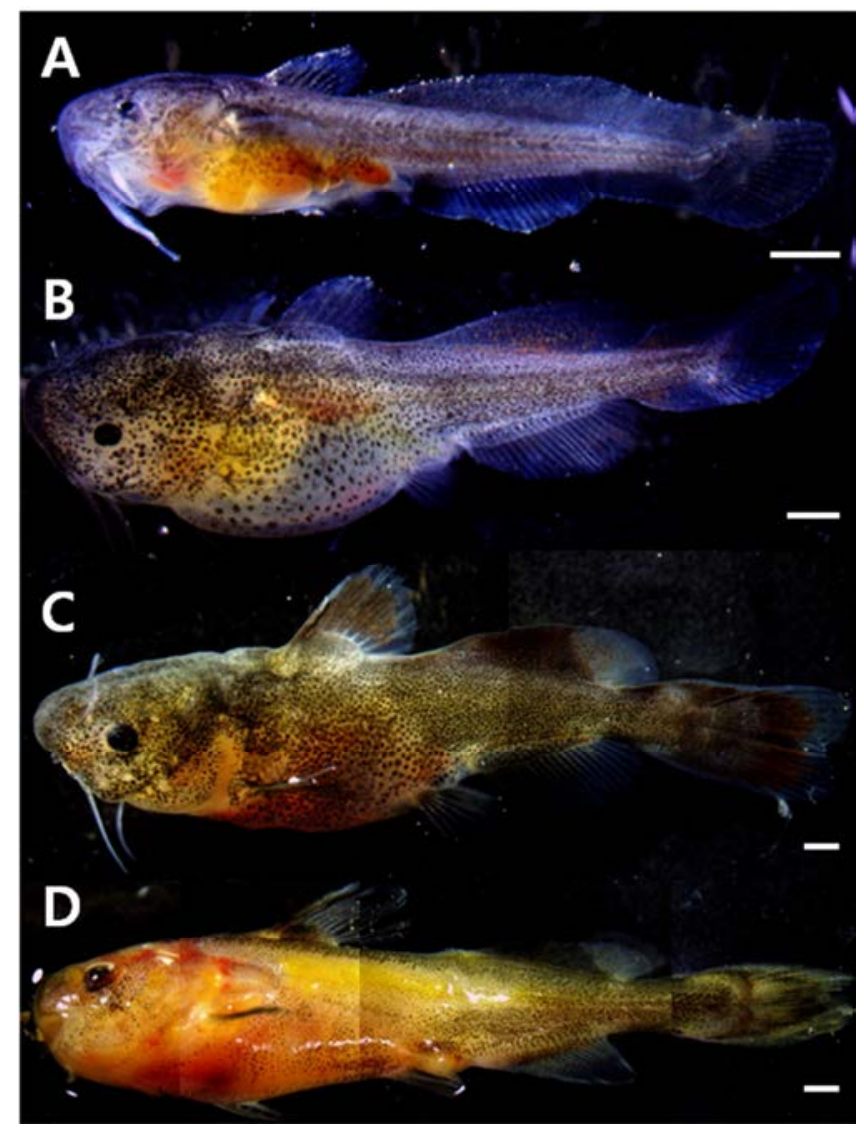

Fig. 3. Development of postlarvae and juveniles Ussurian bullhead fish, Leiocassis ussuriensis. A: $12.5 \mathrm{~mm}$ in TL prelarvae, 10 days after hatching; B: $18.6 \mathrm{~mm}$ in TL prelarvae, 15 days after hatching; C: $25.3 \mathrm{~mm}$ in TL juveniles, 29 days after hatching; D: $31.2 \mathrm{~mm}$ in TL juveniles, 38 days after hatching. Scale bars= $1.0 \mathrm{~mm}$ 
was 30.6 32.5 $\mathrm{mm}$ (average $31.5 \pm 0.65 \mathrm{~mm}$ ), and the number of soft rays in the caudal fin increased to 36. The lateral line was connected long from the center of the gill to the center of the tail. The color of the entire body was dark yellowish brown, and the color of each fin was lighter than the body color. Cannibalism of other individuals did not happen but territory war was observed, and in response to external stimuli, the body color turned yellow and phlegm was discharged (Fig. 3D).

\section{Growth of larva and juvenile}

The average overall length and weight were $6.40 \pm 0.06$ $\mathrm{mm}$ and $0.0107 \mathrm{~g}$ for larvae just after hatching $(\mathrm{n}=10)$, $8.34 \pm 0.09 \mathrm{~mm}$ and $0.0119 \mathrm{~g}$ in 3 days after hatching, $10.6 \pm$ $0.60 \mathrm{~mm}$ and $0.0163 \mathrm{~g}$ in 6 days, and $12.6 \pm 0.67 \mathrm{~mm}$ and $0.0277 \mathrm{~g}$ in 10 days, showing fast growth. The average overall length and weight increased at a high rate to $18.4 \pm$ $0.83 \mathrm{~mm}$ and $0.0927 \mathrm{~g}$ in 15 days after hatching, $25.2 \pm 0.71$
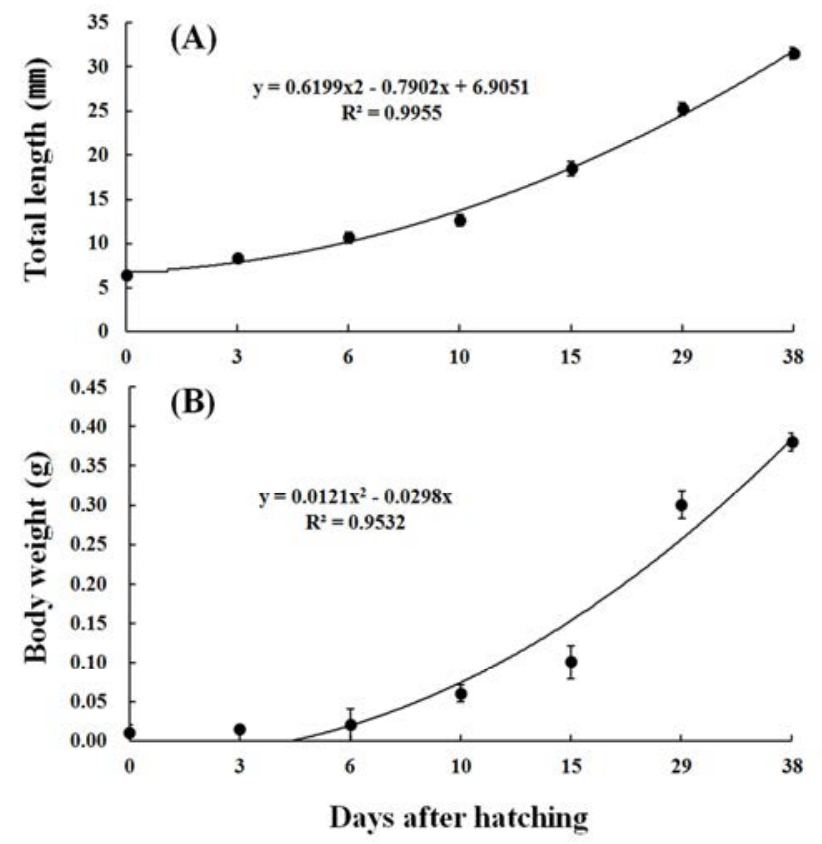

Fig. 4. Early growth of Ussurian bullhead fish, Leiocassis ussuriensis. The change of (A) Total length and (B) Body weight depending on days after hatching. $\mathrm{mm}$ and $0.335 \mathrm{~g}$ in 29 days, and $31.5 \pm 0.65 \mathrm{~mm}$ and 0.384 $\mathrm{g}$ in 38 days. The early growth equation for overall length was $y=0.6199 x^{2}-0.7902 x+6.9051, R^{2}=0.9955$, and that for weight was $\mathrm{y}=0.0121 \mathrm{x}^{2}-0.0298 \mathrm{x}, \mathrm{R}^{2}=0.9532$ (Fig. 4).

\section{DISCUSSION}

Research on the early life history of fish provide various data about fish species including the morphological and physiological characteristics of eggs and the unique traits and developmental characteristics of the species observed through the processes of embryonic development and early growth, and therefore, we can get various types of taxonomic, embryological, and ecological knowledge from such studies (Song \& Choi, 2000; Choi et al., 2008).

This study collected and observed broodstock of Leiocassis ussuriensis, and according to the results, individuals laying matured eggs appeared from early May to mid July and this suggests that the best spawning season is June, which is consistent with the best spawning season reported by Kim (2014). The spawning ground is a river bed covered with sand and mud where the current is slow, and the known spawning behavior is that the male digs mud and then the female lays eggs and the male keeps until hatching (Kim, 2014). Because there is not a report on the results of close observation, however, it may be necessary to make research through the artificial induction of spawning behavior in a breeding tank.

The fertilized egg of Leiocassis ussuriensis was globular, demersal, and adhesive, and the average egg diameter was $2.36 \pm 0.11 \mathrm{~mm}$, which is similar to $2.30 \sim 2.40 \mathrm{~mm}$ reported by Lee (2012). Compared to other species in the same family Bagridae, the egg size was larger than $1.70 \pm 0.08$ $\mathrm{mm}$ (Kang \& Lee, 1996) or 2.04 $\pm 0.07 \mathrm{~mm}$ (Han et al., 2001) for P. fulvidraco, and $1.99 \mathrm{~mm}$ for Pseudobagrus

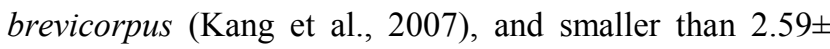
$0.08 \mathrm{~mm}$ for P. koreanus (Kang, 1998). It was smaller than 
$3.27 \mathrm{~mm}$ for Liobagrus mediadiposalis and $3.30 \mathrm{~mm}$ for $L$. obesus in the same order Siluriformes (Choi et al., 2008; Seo et al., 2006).

Lee (2012) reported that time taken for the hatching of Leiocassis ussuriensis eggs was 73 hours 10 minutes at water temperature $25.0 \pm 0.05^{\circ} \mathrm{C}, 120$ hours at $24.0^{\circ} \mathrm{C}$, and 70 hours at $26^{\circ} \mathrm{C}$. This suggests that incubation period is somewhat varied according to water temperature. It took 53 hours at water temperature $25.0^{\circ} \mathrm{C}$ (Kang \& Lee, 1996) and 56 hours at $24.9^{\circ} \mathrm{C}$ (Han et al. 2001) for P. fulvidraco, 72 hours at $21.0 \sim 23.0^{\circ} \mathrm{C}$ for P. koreanus (Kang, 1998), 50 hours at $24.0^{\circ} \mathrm{C}$ for Pseudobagrus brevicorpus (Kang et al., 2007), 189 hours 20 minutes at $22.5^{\circ} \mathrm{C}$ for Liobagrus mediadiposalis (Choi et al., 2008), and 225 hours 15 minutes at $22.8^{\circ} \mathrm{C}$ for L. obesus. In the fishes of order Siluriformes, incubation tended to be shorter at high water temperature, and Leiocassis ussuriensis took a longer time to hatch than $P$. fulvidraco at the same water temperature (Kang \& Lee, 1996). P. koreanus was bred at lower water temperature (below $23.0^{\circ} \mathrm{C}$ ) than Leiocassis ussuriensis but the period of incubation was similar (Kang, 1998).

The overall length of larvae just after hatching was $6.40 \pm 0.06 \mathrm{~mm}$ for Leiocassis ussuriensis, which was longer than 4.20 4.30 mm (Kang \& Lee, 1996) or $4.92 \mathrm{~mm}$ (Han et al., 2001) for P. fulvidraco, 5.41 6.01 mm for P. koreanus (Kang, 1998), and $5.90 \mathrm{~mm}$ for Pseudobagrus brevicorpus (Kang et al., 2007), and shorter than $7.31 \mathrm{~mm}$ for Liobagrus mediadiposalis (Choi et al., 2008), and $7.66 \mathrm{~mm}$ for L. obesus (Seo et al., 2006), showing differences among the species.

The time for transition to the juvenile stage was 29 days after hatching with average overall length $25.2 \pm 0.71 \mathrm{~mm}$ for Leiocassis ussuriensis. It was later than 21 days after hatching (body length $21.6 \sim 24.0 \mathrm{~mm}$ ) or 23 days (26.0 $\mathrm{mm})$ for $P$. fulvidraco, 14 days $(14.6 \sim 16.0 \mathrm{~mm})$ for $P$. koreanus, 8 days $(8.60 \mathrm{~mm})$ for Pseudobagrus brevicorpus, and 24 days $(16.3 \mathrm{~mm})$ for L. obesus, but earlier than that for Liobagrus mediadiposalis (Table 1).

The fishes of order Siluriformes are similar in the form of larva and commonly have barbels formed around the

Table 1. Comparison characters of the eggs and larvae characters in the Siluriformes fishes

\begin{tabular}{|c|c|c|c|c|c|}
\hline Species & $\begin{array}{c}\text { Egg diameter } \\
(\mathrm{mm}, \text { mean } \pm \mathrm{SD})\end{array}$ & $\begin{array}{l}\text { Time of hatching } \\
(* \mathrm{WT})\end{array}$ & $\begin{array}{c}\text { Hatching } \\
\text { larvae size } \\
(\mathrm{mm}, \text { mean } \pm \mathrm{SD})\end{array}$ & $\begin{array}{c}\text { Juvenile size } \\
(\mathrm{mm}, \text { mean } \pm \mathrm{SD})\end{array}$ & References \\
\hline Leiocassis ussuriensis & $\begin{array}{r}2.36 \pm 0.11 \\
(2.20 \sim 2.50)\end{array}$ & $\begin{array}{l}73 \text { h } 10 \text { mins } \\
\left(24.5 \sim 26.5^{\circ} \mathrm{C}\right)\end{array}$ & $\begin{array}{r}6.40 \pm 0.06 \\
(6.33 \sim 6.50)\end{array}$ & $\begin{array}{c}25.2 \pm 0.71 \\
(24.3 \sim 26.2)\end{array}$ & Present study \\
\hline Pseudobagrus fulvidraco & $\begin{array}{c}1.70 \pm 0.08 \\
(1.60 \sim 1.80)\end{array}$ & $\begin{array}{c}53 \mathrm{~h} \\
\left(25.0^{\circ} \mathrm{C}\right)\end{array}$ & $(4.20 \sim 4.30)$ & $(21.6 \sim 24.0)$ & Kang \& Lee, 1996 \\
\hline Pseudobagrus fulvidraco & $2.04 \pm 0.07$ & $\begin{array}{c}56 \mathrm{~h} \\
\left(24.9^{\circ} \mathrm{C}\right)\end{array}$ & $\begin{array}{c}4.92 \pm 0.33 \\
(4.26 \sim 5.51)\end{array}$ & $\begin{array}{c}26.0 \pm 0.67 \\
(25.1 \sim 27.5)\end{array}$ & Han et al., 2001 \\
\hline Pseudobagrus brevicorpus & 1.99 & $\begin{array}{c}50 \mathrm{~h} \\
\left(24.0^{\circ} \mathrm{C}\right)\end{array}$ & $5.90 \pm 0.20$ & $8.60 \pm 0.50$ & Kang et al., 2007 \\
\hline Pseudobagrus koreanus & $\begin{array}{c}2.59 \pm 0.08 \\
(2.45 \sim 2.70)\end{array}$ & $\begin{array}{c}72 \mathrm{~h} \\
\left(21.0 \sim 23.0^{\circ} \mathrm{C}\right)\end{array}$ & $(5.41 \sim 6.01)$ & $(14.6 \sim 16.0)$ & Kang, 1998 \\
\hline Liobagrus mediadiposalis & $\begin{array}{c}3.27 \\
(2.85 \sim 3.73)\end{array}$ & $\begin{array}{c}189 \mathrm{~h} 20 \mathrm{mins} \\
\left(22.5^{\circ} \mathrm{C}\right)\end{array}$ & $\begin{array}{c}7.31 \\
(7.18 \sim 7.39)\end{array}$ & 16.3 & Choi et al., 2008 \\
\hline Liobagrus obesus & $\begin{array}{c}3.30 \\
(2.95 \sim 3.92)\end{array}$ & $\begin{array}{c}225 \mathrm{~h} 15 \mathrm{mins} \\
\left(22.8^{\circ} \mathrm{C}\right)\end{array}$ & $\begin{array}{c}7.66 \\
(7.30 \sim 7.90)\end{array}$ & 16.3 & Seo et al., 2006 \\
\hline
\end{tabular}

*WT : Water temperature 
mouth, so it is difficult to distinguish them. For Leiocassis ussuriensis, all of the four pairs of barbels were formed in 15 days after hatching, which was later than 7 days for $P$. fulvidraco (Kang \& Lee, 1996), 5 days for P. koreanus (Kang, 1998), 4 days for Pseudobagrus brevicorpus (Kang et al., 2007), and just after hatching for Liobagrus mediadiposalis (Choi et al., 2008) and L. obesus (Seo et al., 2006).

The fishes of family Bagridae are taxonomically noteworthy because they show various differences in spawning behavior, incubation period, outer form, skeletal characteristics, etc., and though different in genus, they are reported to be similar in the surface structure of egg membrane, the state of motion of the yolk, etc. (Kang, 1998) and therefore, these characteristics are believed to be important in future research for inter-species comparison of characteristics.

\section{REFERENCES}

Bang IC, Baek JM (2011) Development of seedling production technique in early out of season for Korean bullhead, Pseudobagrus fulvidraco. Soonchunhyang Univ pp.15-105.

Choi NH, Seo WI, Kim CC, Park CK, Heo SJ, Yoon SM, Han KH, Lee WK (2008) Spawning behavior and early life history of the Liobagrus mediadiposalis in the Korean endemic species. J Korean Fish Soc 41:478-484.

Han KN, Nam KB, Jeong CH (2001) Development of eggs, larvae and juvenile of the Korean bullhead, Pseudobagrus fulvidraco(Richardson) reared in the laboratory. Korean J Ichthyol 13:74-84.

Kendall AW Jr, Ahlstrom EH, Moser HG (1984) Early life history stages of fishes and their characters. In: Moser HG et al. (eds). Ontogeny and Systematics of Fishes. Am Soc Ichthyol Herpetol Spec Publ 1:11-22 Allen Press Lawrence KS.
Kang EJ, Lee CH (1996) Early life history of Korean bullhead, Pseudobagrus fulvidraco (Pisces, Bagridae), from Korea. Korean J Ichthyol 8:83-89.

Kang EJ (1998) Early life history of black bullhead, Pseudobagrus koreanus (Pisces, Bagridae), from kum river Korea. Korean J Ichthyol 10:184-190.

Kang EJ, Yang H, Lee, HH, Cho YC, Kim EO, Lim SG, Bang IC (2007). Ecology and early life history of endangered freshwater fish Pseudobagrus brevicorpus (Pisces: Bagridae). Korean J Environ Biol 25:378384.

Kim IS, Choi Y, Lee CL, Lee YJ, Kim BJ, Kim JH (2005) Illustrated Book of Korean Fishes. Kyo Hak Publishing Seoul Korean pp.43.

Kim IS (2014) Freshwater Fish Illustrated Book. Bori Publishing Korean pp.236-245.

Lee CL, Kim IS (1990) A Taxonomic revision of the family bagridae (Pisces, Siluriformes) from Korea. Korean J Ichthyol 2: 117-137. (in Korean)

Lee BB (2012) Aquaculture of freshwater Korean bullhead and bagrid catfish. Chungcheongbuk-do Inland Fisheries Research Institute pp. 25-39.

Lim SG (2009) A study on the aquaculture of long snout bullhead and bagrid catfish. Report of National Fisheries Research \& Development Institute pp.162 .

Matsuo T, Takahana H (2004) Mating behavior of the freshwater catfish Pseudobagrus nudiceps (Siluriformes: Bagridae) in an aquarium. Japan J Ichthyol 51: 169-174.

NIBR (2011) National list of species of Korea (Vertebrates). National Institute of Biological Resources pp.143-145.

Park HY, Lee JY, Lee YJ, Kwon HC (1998) Induction 
of ovulation by LHRH-a and pimozide in the bullhead, Pseudobagrus fulvidraco. J of Aquaculture 11:151-158.

Song HB, Choi SS (2000) Reproductive ecology and early life history of paradise fish, Macropodus chinensis (Pisces: Belontidae) in aquarium. Korean J Limnol 33:282-294.

Seo WI, Han KH, Yoon SM, Kim CC, Hwang SY, Lee SH, Lee CL, Son YM, Kim IS (2006) Early life history of the Liobagrus obesus (Pisces, Amblycipitidae). Dev Reprod 10:41-45.

Takeshita N, Kimura S (1994) Eggs, larvae and juveniles of the Bagridae fish, Pseudobagrus aurantiacus, from the Chikugo river, Kyushu Island, Japan. Japan J Ichthyol 40:504-508.

Watanabe K (1994) Mating behavior and larval development of Pseudobagrus ichikawai (Siluriformes: Bagridae). Japan J Ichthyol 41:243-251. 